\title{
O jovem como sujeito social
}

Juarez Dayrell

Universidade Federal de Minas Gerais, Faculdade de Educação

\section{Introdução}

Neste artigo tratamos de jovens ligados a grupos musicais, especificamente de rappers e funkeiros. Mas a discussão não será em torno dos estilos rap e funk em si mesmos, o que de alguma forma já discuti em artigos anteriores. ${ }^{1}$ Proponho um olhar sobre os jovens para além dos grupos musicais, buscando compreendê-los como sujeitos sociais que, como tais, constroem um determinado modo de ser jovem. Ou seja, a pergunta sobre quem são esses jovens que participam de grupos de rap e funk.

Ao analisar a produção teórica sobre os grupos musicais juvenis no Brasil, pelo menos aquelas a que tivemos acesso, ${ }^{2}$ percebi uma tendência na descrição e análise dos grupos em si mesmos, possibilitando o

${ }^{1}$ Ver Dayrell (1999, 2001, 2002a, 2002b).

${ }^{2}$ Vianna (1987); Sposito (1993); Kemp (1993); Costa (1993); Abramo (1994); Guerreiro (1994); Guimarães (1995); Andrade (1996); Cechetto (1997); Silva (1998); Arce (1999); Herschmann (2000); Tella (2000). conhecimento da sua realidade cotidiana, a forma como constroem o estilo, os significados que lhe atribuem e o que expressam no contex to de uma sociedade cada vez mais globalizada. Esses estudos muito contribuíram para problematizar a cultura juvenil contemporânea, evidenciando, por meio dela, os anseios e os dilemas vividos pela juventude brasileira.

Contudo, apesar de suas contribuições, essa produção teórica apresenta uma lacuna. Ao construírem o seu objeto, tais investigações recortam de tal forma a realidade dos jovens que dificultam a sua compreensão como sujeitos, na sua totalidade. Podemos até conhecer o jovem como um rapper ou um funkeiro, mas sabemos muito pouco a respeito do significado dessa identidade no conjunto que, efetivamente, faz com que ele seja o que é naquele momento.

Por outro lado, nos deparamos no cotidiano com uma série de imagens a respeito da juventude que interferem na nossa maneira de compreender os jovens. Uma das mais arraigadas é a juventude vista na sua condição de transitoriedade, na qual o jovem é um "vir a ser", tendo no futuro, na passagem para a vida adulta, o sentido das suas ações no presente. Sob essa 
perspectiva, há uma tendência de encarar a juventude na sua negatividade, o que ainda não chegou a ser (Salem, 1986), negando o presente vivido. Essa concepção está muito presente na escola: em nome do "vir a ser" do aluno, traduzido no diploma e nos possíveis projetos de futuro, tende-se a negar o presente vivido do jovem como espaço válido de formação, assim como as questões existenciais que eles expõem, bem mais amplas do que apenas o futuro.

Uma outra imagem presente é uma visão romântica da juventude que veio se cristalizando a partir dos anos de 1960, resultado, entre outros fatores, do florescimento da indústria cultural e de um mercado de consumo dirigido aos jovens, que se traduziu, em modas, adornos, locais de lazer, músicas, revistas etc. (Leccardi, 1991; Abramo, 1994; Feixa, 1998). Nessa visão, a juventude seria um tempo de liberdade, de prazer, de expressão de comportamentos exóticos. A essa idéia se alia a noção de moratória, como um tempo para o ensaio e o erro, para experimentações, um período marcado pelo hedonismo e pela irresponsabilidade, com uma relativização da aplicação de sanções sobre o comportamento juvenil. Mais recentemente, acrescenta-se uma outra tendência de perceber o jovem reduzido apenas ao campo da cultura, como se ele só expressasse a sua condição juvenil nos finais de semana ou quando envolvido em atividades culturais.

Essas imagens convivem com outra: a juventude vista como um momento de crise, uma fase difícil, dominada por conflitos com a auto-estima e/ou com a personalidade. Ligada a essa idéia, existe uma tendência em considerar a juventude como um momento de distanciamento da família, apontando para uma possível crise da família como instituição socializadora. Alguns autores vêm ressaltando que a família, junto com o trabalho e a escola, estaria perdendo o seu papel central de orientação e de valores para as gerações mais novas (Morcellini, 1997; Zaluar, 1997; Abromavay et al.,1999).

Torna-se necessário colocar em questão essas imagens, pois, quando arraigados nesses "modelos" socialmente construídos, corremos o risco de anali- sar os jovens de forma negativa, enfatizando as características que lhes faltariam para corresponder a um determinado modelo de "ser jovem". Dessa forma, não conseguimos apreender os modos pelos quais os jovens, principalmente se forem das camadas populares, constroem as suas experiências.

Com base nessas preocupações, pretendo evidenciar neste artigo como os jovens, enquanto sujeitos sociais, constroem um determinado modo de ser jovem, baseados em seu cotidiano. Para isso tomaremos como foco jovens das camadas populares ligados a grupos musicais, no caso, rap e funk. ${ }^{3}$ Quem são esses jovens fora dos grupos dos quais participam? Como constroem um determinado modo de ser jovem no seu cotidiano?

Para desenvolver tais questões, torna-se necessário explicitar meu olhar sobre a juventude, bem como minha compreensão do jovem como sujeito social. Comecemos por essa discussão.

\section{Juventude? Juventudes...}

Construir uma definição da categoria juventude não é fácil, principalmente porque os critérios que a constituem são históricos e culturais. Uma série de autores já se debruçou sobre o tema, trazendo importantes contribuições, não sendo meu propósito aqui recuperar toda essa discussão. ${ }^{4}$ Neste artigo, me limitarei a explicitar a minha posição, ressaltando a dimensão da diversidade presente na mesma.

Entendemos, como Peralva (1997), que a juventude é, ao mesmo tempo, uma condição social e um tipo de representação. Se há um caráter universal dado pelas transformações do indivíduo numa determina-

${ }^{3}$ Os dados empíricos utilizados são parte da pesquisa que resultou na tese de doutorado intitulada A música entra em cena: o rap e o funk na socialização da juventude em Belo Horizonte (Dayrell, 2001).

${ }^{4}$ Para uma discussão mais aprofundada a respeito da noção de juventude, ver Pais (1993); Sposito (1993, 2000); Peralva (1997); Feixa (1998); Dayrell (1999, 2001), entre outros. 
da faixa etária, nas quais completa o seu desenvolvimento físico e enfrenta mudanças psicológicas, é muito variada a forma como cada sociedade, em um tempo histórico determinado, e, no seu interior, cada grupo social vão lidar com esse momento e representá-lo. Essa diversidade se concretiza com base nas condições sociais (classes sociais), culturais (etnias, identidades religiosas, valores) e de gênero, e também das regiões geográficas, dentre outros aspectos.

Construir uma noção de juventude na perspectiva da diversidade implica, em primeiro lugar, considerá-la não mais presa a critérios rígidos, mas sim como parte de um processo de crescimento mais totalizante, que ganha contornos específicos no conjunto das experiências vivenciadas pelos indivíduos no seu contexto social. Significa não entender a juventude como uma etapa com um fim predeterminado, muito menos como um momento de preparação que será superado com o chegar da vida adulta. Nessa direção, Melucci (apud Melucci \& Fabbrini, 1992) nos propõe uma outra forma de compreender a adolescência e a juventude. Para ele, existe uma seqüência temporal no curso da vida, cuja maturação biológica faz emergir determinadas potencialidades. Nesse sentido, é possível marcar um início da juventude, quando fisicamente se adquire a capacidade de procriar, quando a pessoa dá sinais de ter necessidade de menos proteção por parte da família, quando começa a assumir responsabilidades, a buscar a independência e a dar provas de auto-suficiência, dentre outros sinais corporais e psicológicos.

Mas, para o autor, uma sequiência temporal não implica necessariamente uma evolução linear, na qual ocorra uma complexidade crescente, com a substituição das fases primitivas pelas fases mais maduras, de tal forma a cancelar as experiências precedentes. Melucci, ao contrário, defende a idéia de que os fenômenos evolutivos presentes nas mudanças dos ciclos vitais são fatos que dizem respeito a cada momento da existência, fazendo das mudanças ou transformações uma característica estável da vida do indivíduo. Assim, a adolescência não pode ser entendida como um tempo que termina, como a fase da crise ou de trânsito entre a infância e a vida adulta, entendida como a última meta da maturidade. Mas representa o momento do início da juventude, um momento cujo núcleo central é constituído de mudanças do corpo, dos afetos, das referências sociais e relacionais. Um momento no qual se vive de forma mais intensa um conjunto de transformações que vão estar presentes, de algum modo, ao longo da vida.

Dessa discussão, entendemos a juventude como parte de um processo mais amplo de constituição de sujeitos, mas que tem especificidades que marcam a vida de cada um. A juventude constitui um momento determinado, mas não se reduz a uma passagem; ela assume uma importância em si mesma. Todo esse processo é influenciado pelo meio social concreto no qual se desenvolve e pela qualidade das trocas que este proporciona. Assim, os jovens pesquisados constroem determinados modos de ser jovem que apresentam especificidades, o que não significa, porém, que haja um único modo de ser jovem nas camadas populares. É nesse sentido que enfatizamos a noção de juventudes, no plural, para enfatizar a diversidade de modos de ser jovem existentes. Assim compreendida, tornase necessário articular a noção de juventude à de sujeito social.

\section{O s jovens como sujeitos sociais}

Geralmente, a noção de sujeito social é tomada com um sentido em si mesma, sem a preocupação de defini-la, como se fosse consensual a compreensão do seu significado. Outras vezes é tomada como sinônimo de indivíduo, ou mesmo de ator social. Para alguns, falar em "sujeito" implica uma condição que se alcança, definindo-se alguns pré-requisitos para tal; para outros, é uma condição ontológica, própria do ser humano. Nos limites deste artigo não cabe uma discussão que recupere a construção do conceito, assim me limitarei a assumir determinada posição.

Para efeitos desta análise, assumi a definição de Charlot (2000, p. 33 e 51), para quem o sujeito é um ser humano aberto a um mundo que possui uma historicidade; é portador de desejos, e é movido por eles, 
além de estar em relação com outros seres humanos, eles também sujeitos. Ao mesmo tempo, o sujeito é um ser social, com uma determinada origem familiar, que ocupa um determinado lugar social e se encontra inserido em relações sociais. Finalmente, o sujeito é um ser singular, que tem uma história, que interpreta o mundo e dá-lhe sentido, assim como dá sentido à posição que ocupa nele, às suas relações com os outros, à sua própria história e à sua singularidade. Para o autor, o sujeito é ativo, age no e sobre o mundo, e nessa ação se produz e, ao mesmo tempo, é produzido no conjunto das relações sociais no qual se insere.

Charlot relaciona a noção de sujeito às características que definem a própria condição antropológica que constitui o ser humano, ou seja, o ser que é igual a todos como espécie, igual a alguns como parte de um determinado grupo social e diferente de todos como um ser singular. Nessa perspectiva, o ser humano não é um dado, mas uma construção. A condição humana é vista como um processo, um constante tornar-se por si mesmo, no qual o ser se constitui como sujeito à medida que se constitui como humano, com o desenvolvimento das potencialidades que o caracterizam como espécie.

Charlot (2000) lembra ainda que a essência originária do indivíduo humano não está dentro dele mesmo, mas sim fora, em uma posição excêntrica, no mundo das relações sociais. Trata-se da outra face da condição humana a ser desenvolvida: a sua natureza social. Dizer que a essência humana é antes de tudo social é o mesmo que afirmar que o homem se constitui na relação com o outro.

Ao mesmo tempo, a alteridade, vista nessa perspectiva, mostra que o ser humano se coloca no limite entre a natureza e a cultura: a dimensão biológica e a social influenciam-se mutuamente na produção humana. A possibilidade de o ser humano se constituir como tal depende tanto do seu desenvolvimento biológico, em especial do sistema nervoso, quanto da qualidade das trocas que se dão entre os homens no meio no qual se insere. $\mathrm{O}$ homem se constitui como ser biológico, social e cultural, dimensões totalmente interligadas, que se desenvolvem com base nas rela- ções que estabelece com o outro, no meio social concreto em que se insere.

Podemos concluir que o pleno desenvolvimento ou não das potencialidades que caracterizam o ser humano vai depender da qualidade das relações sociais desse meio no qual se insere. Assim, concordo com Charlot, quando afirma que todo ser humano é sujeito. Mas temos de levar em consideração que existem várias maneiras de se construir como sujeito, e uma delas se refere aos contextos de desumanização, nos quais o ser humano é "proibido de ser", privado de desenvolver as suas potencialidades, de viver plenamente a sua condição humana, como foi possível constatar em grande parte dos jovens pesquisados. Não é que eles não se construam como sujeitos, ou o sejam pela metade, mas sim que eles se constroem como tais na especificidade dos recursos de que dispõem. É essa realidade que nos leva a perguntar se esses jovens não estariam nos mostrando um jeito próprio de viver.

Quando cada um desses jovens nasceu, a sociedade já tinha uma existência prévia, histórica, cuja estrutura não dependeu desse sujeito, portanto, não foi produzida por ele. Assim, o gênero, a raça, o fato de terem como pais trabalhadores desqualificados, grande parte deles com pouca escolaridade, dentre outros aspectos, são dimensões que vão interferir na produção de cada um deles como sujeito social, independentemente da ação de cada um. Ao mesmo tempo, na vida cotidiana, entram em um conjunto de relações e processos que constituem um sistema de sentidos, que dizem quem ele é, quem é o mundo, quem são os outros. É o nível do grupo social, no qual os indivíduos se identificam pelas formas próprias de vivenciar e interpretar as relações e contradições, entre si e com a sociedade, o que produz uma cultura própria.

Meu contato com os jovens que pesquisei deixa muito claro o aparente óbvio: eles são seres humanos, amam, sofrem, divertem-se, pensam a respeito de suas condições e de suas experiências de vida, posicionam-se, possuem desejos e propostas de melhoria de vida. Acreditamos que é nesse processo que cada um deles vai se construindo e sendo construído 
como sujeito: um ser singular que se apropria do social, transformado em representações, aspirações e práticas, que interpreta e dá sentido ao seu mundo e às relações que mantém.

Tomar os jovens como sujeitos não se reduz a uma opção teórica. Diz respeito a uma postura metodológica e ética, não apenas durante o processo de pesquisa mas também em meu cotidiano como educador. A experiência da pesquisa mostrou-me que ver e lidar com o jovem como sujeito, capaz de refletir, de ter suas próprias posições e ações, é uma aprendizagem que exige um esforço de auto-reflexão, distanciamento e autocrítica. A dificuldade ainda é maior quando o outro é "jovem, preto e pobre", essa tríade que acompanha muitos dos jovens como uma maldição.

Da mesma forma, acredito que este artigo não apenas fala dos jovens, mas fala dos jovens na sua relação com o pesquisador, e vice-versa. É resultado de um modo de observar centrado nas relações. Significa dizer que os jovens não são apenas objeto da observação, mas pessoas em relação com aquele que observa. Tenho claro que construi um texto que se refere a fatos socialmente construídos, com a consciência da distância que separa a interpretação da "realidade".

\section{O s sujeitos da pesquisa}

Para desenvolver essa reflexão, optei por privilegiar dois jovens que serão os fios condutores da análise: João é um rapper; Flavinho é um funkeiro. ${ }^{5}$ Não tenho o propósito de tratá-los como modelos. Eles são sujeitos concretos, com experiências singulares, cujas trajetórias de vida podem fornecer elementos para melhor compreendê-los além da identidade como

${ }^{5} \mathrm{~A}$ escolha desses jovens se deu na última fase da pesquisa, depois de uma série de passos metodológicos, entre eles a realização de uma pesquisa telefônica com 146 grupos musicais juvenis, e a escolha de seis grupos de rap e funk. Com esses dois jovens mantivemos contatos intensos, além de entrevistas em profundidade. Para maiores detalhes da metodologia, ver Dayrell (2001). rappers ou funkeiros. Os dois jovens expressam experiências e momentos de vida diferenciados, revelando mundos próprios.

\section{João e a "correria" de um rapper}

João é um rapper, integrante do grupo Máscara Negra. Tem 22 anos, é negro e mora com sua mãe e um irmão. A mãe trabalhava como cozinheira em bares e casas de família, estando atualmente aposentada por motivos de saúde. A sobrevivência da família é garantida pela contribuição de todos no orçamento doméstico, sendo que João é o que menos contribui, numa estratégia de liberá-lo para investir na sua carreira musical. Isso mostra que sua família vê na música, no rap, uma carreira possível.

João considera que as relações familiares são muito importantes para a sua vida ("Eu gosto da minha mãe e do meu irmão pra caralho...”). Todas as vezes que ele se refere à mãe ou ao irmão, o faz com admiração, evidenciando a importância que lhes atribui na sua formação. João enfatiza a importância atual da prática do diálogo e das negociações no interior da família no seu amadurecimento, diferente do clima de conflitos constantes quando mais novo.

Agora lá em casa sempre rolou muita conversa. Sempre foi tudo aberto, assunto de sexo, assunto de música, tudo rola, até assunto de televisão. Acho que é isso que me ajudou muito a não ter um filho até hoje, essa história de não ter feito muita treta (malandragem). A gente sempre fala aberto...

João trabalha desde os 13 anos, nos mais diferentes "bicos", sendo atualmente meio-oficial de serralheiro. No período em que o acompanhei não tinha um emprego fixo, gastando boa parte do seu tempo procurando trabalho, dirigindo-se às serralherias do bairro para ver se encontrava algum "bico" para fazer, ganhando $\mathrm{R} \$ 10,00$ por dia. Ele não se sente um profissional na ocupação que exerce, muito menos gosta do que faz: "[A serralheria] é um trampo que eu mais detesto, cara! Se ocê soubesse o que que é quei- 
mar o olho na solda; o que que é ficar sem dormir por causa das vista queimada. Eu vou te falar, é brabo...".

Nas suas experiências no mundo do trabalho não esteve e não está presente a dimensão da escolha, o trabalho sendo encarado como uma obrigação necessária. Convive com o conflito entre o tempo de trabalho e o tempo das atividades musicais, quando o primeiro restringe as possibilidades de investir na música, que é aquilo que gosta e que o faz se sentir produtivo. Comentando sobre um dos poucos empregos fixos que já teve, lembra:

Chegava dentro da firma e minha cabeça num era pra aquilo lá, trabalhei em muitos lugares, cara, mas minha cabeça num aceitava... era aquele trauma, ficava nervoso porque eu pensava: "Pô, eu tenho de fazer é música, o meu negócio é aquilo lá, é só com isso que eu me entretenho, é nisso que eu tenho uma vontade, cara!"

O grande sonho de João é sobreviver da música, ou pelo menos de alguma atividade em torno do mundo da cultura.

Ele foi excluído da escola na $5^{\text {a }}$ série do ensino fundamental, não retomando os estudos desde então. A escola é lembrada como um espaço que não o envolvia, distante dos seus interesses e necessidades: “A escola não me cativava, não me despertava interesse, era um saco... aí eu fui desinteressando pelo estudo...". Lembra com mágoa das três reprovações; da imagem de mau aluno que tinha, envolvido em brigas e discussões com as professoras. Segundo ele, a única lembrança boa é de uma professora que mandou um bilhete para a sua mãe, dizendo "[...] que eu era carente e que eu precisava de carinho. Que eu não era tão moleque como minha mãe imaginava. Depois disso, né, fiquei na maior empolgação com ela, eu até me apaixonei com ela". Além disso, havia a necessidade e o desejo de trabalhar, para atender às demandas mínimas de consumo e lazer. Atualmente reconhece que a falta de um diploma diminui suas possibilidades no mercado de trabalho e se diz arrependido de não ter concluído o ensino básico, o que contribui para minar a sua auto-estima.
No contexto em que João veio sendo socializado, o hip hop, e especificamente o rap, ${ }^{6}$ cumpriu e ainda cumpre um papel significativo na sua vida. Ele veio construindo a sua vida, a sua rede de relações e os seus projetos em torno desse estilo, ${ }^{7}$ o que muito interferiu na forma como ele se representa, na visão de mundo que possui e nos comportamentos e valores que expressa, constituindo um estilo de vida.

João aderiu ao hip hop desde a adolescência, inicialmente participando de gangues de break, com quem frequientava os bailes, além de participar dos rachas e competições na região onde morava. Segundo ele, a adesão ao hip hop contribuiu para o aprimoramento do seu gosto musical e para a descoberta de suas potencialidades artísticas como produtor musical e cantor. Ao mesmo tempo, possibilitou-lhe uma ampliação do domínio do espaço urbano além do bairro, pois passou a freqüientar festas em diferentes regiões da cidade, aumentando, assim, a sua rede de relações.

Com o hip hop passei a andar pra tudo quanto é lado. Onde achava que tinha alguma coisa, a gente ia. Num tinha limite, não. Tem uma festa em tal lugar? Rola? Vamo embora: bairro São Paulo, bairro Nacional, Industrial, no Eldorado, tudo que é canto...

Em 1995 formou o Máscara Negra junto com três amigos, com os quais atua até hoje. Eles apresentam-se em festas de rua e eventos de hip hop, possuindo uma certa projeção no meio.

${ }^{6}$ Rap, palavra formada pelas iniciais da expressão rhythm and poetry (ritmo e poesia) é a linguagem musical do movimento hip hop, um estilo juvenil que agrega outras linguagens artísticas como as artes plásticas, o grafite, a dança, o break e a discotecagem, o DJ. Para maiores informações sobre o estilo, ver Sposito (1993), Andrade (1996), Silva (1998), Tella (2000), entre outros.

${ }^{7}$ Estamos entendendo estilo como uma manifestação simbólica das culturas juvenis, que expressa um conjunto mais ou menos coerente de elementos materiais e imateriais que os jovens consideram representativos da sua identidade individual e coletiva (Feixa, 1998). 
João se encontra com o grupo com muita regularidade, estando juntos praticamente todas as noites para ensaios, produção de músicas ou para saírem juntos. Ele admite que já tiveram e ainda têm muitos atritos entre si, mas vieram aprendendo a conviver com as diferenças, estreitando as relações. A amizade, junto com os interesses comuns, faz do grupo uma referência importante para cada um deles; João enfatiza as relações de confiança existentes: podem contar uns com os outros, trocando idéias sobre a vida pessoal e afetiva, construindo uma identidade coletiva, mas também individual. Outro esteio com o qual conta é a namorada, numa relação valorizada pelo que ela significa de afirmação e estímulo para enfrentar as dificuldades e implementar os seus projetos. Para João, o seu namoro é um dos fatores que o levam à transição para o mundo adulto, interferindo nas suas opções. Outra referência, mas menos intensa, são os colegas, quase todos ligados ao movimento hip hop, com os quais se encontra nos momentos de lazer.

João já se defronta com os dilemas típicos da passagem para a vida adulta, ele mesmo se considerando um jovem adulto. $\mathrm{O}$ aumento das responsabilidades em casa e o próprio noivado são sinalizações desse momento:

Hoje eu tô preocupado em arrumar outras coisas, eu tenho noiva, que vem coisa séria, vem o grupo, ocê passa a olhar mesmo a situação sua dentro de casa e tudo. Aí ocê passa a ficar um pouco mais sério, ocê entendeu? Hoje em dia meus amigos é pouco, porque assim meus amigos foi muito de zuera, né, e vai acabando esses tipo de amizade assim de zuera. Nem todo mundo tem esse processo, mas eu tive. Ocê fica mais sério, a gente vai ficando adulto, né, véio...

No momento das entrevistas, estava colocando em questão a sua opção pela música, questionandose sobre as escolhas realizadas até então e as perspectivas de futuro. Nesse contexto ele expressa uma certa representação socialmente construída do adulto, presente no meio popular, que apresenta algumas polaridades em relação ao jovem, como: sério $x$ zoador; responsável $x$ irresponsável. Diante dessas imagens, há a exigência de uma nova postura. Se antes o que o mobilizava era a diversão, agora ele exige de si mesmo maior seriedade. A própria turma de amigos torna-se mais reduzida, fruto de um processo de seleção. Essa postura se concretizava na divisão de tempo, na escolha dos programas com os quais ocupava as horas livres. Nessa época, os finais de semana eram dedicados principalmente ao namoro, com a noiva acompanhando-o aos shows nos quais o grupo se apresentava. Além disso, costumava freqüentar bares e festas de hip hop, sempre com os amigos mais próximos. Mas não deixava de "dar um rolé” em bares ou rodas de samba, dos quais gosta muito.

Podemos constatar que, no contexto no qual João veio se construindo, o rap foi e é um dos poucos espaços, além da família, em que encontra apoio, pode estabelecer trocas e elabora projetos que dão sentido à sua vida no presente. Naquele momento, ele elaborava um projeto de vida:

Meu trabalho é a música e o que trampo que ela gera... É isso que eu quero, ser respeitado dentro do campo musical... Eu quero conseguir um poder aquisitivo, um financeiro melhor, isso é lógico, quem viveu a vida inteira na pobreza é lógico que quer subir na vida... [pausa]. Resumindo, isso aí mesmo. Coisa simples. No mais, quero casar, é lógico... Sou noivo, é minha idade, né? E ver minha mãe melhor, esses trens assim. Dar à minha mãe o que ela não teve, coisas assim, que todo mundo pensa.

O que João expressa por intermédio do rap é o desejo de realizar-se. Implica ser um artista profissional, ser respeitado como um criador musical, ter uma vida digna para si e sua família, com um mínimo de condições financeiras, casar-se e ter sua própria família. Tudo muito simples, como ele diz, e ao mesmo tempo tão distante.

\section{Flavinho: um funkeiro imerso no presente}

Flavinhoé um funkeiro, participando de uma dupla com Leo. Ele tem 19 anos e é branco. É um exemplo 
do jovem que vive plenamente a sua condição juvenil, com tempo livre para dedicar-se ao funk, aos amigos e à namorada.

É o filho mais novo entre quatro irmãos, todos vivendo com a mãe, uma operária têxtil. Residem em casa própria, em um conjunto habitacional localizado em um bairro da periferia norte de Belo Horizonte. $\mathrm{O}$ pai saiu de casa há sete anos e ele nunca mais o viu.

Flavinho, a exemplo de outros jovens pesquisados, diz ter uma relação mais estreita com a mãe, com quem conversa mais. Mas quando compara a sua família com a de outros amigos, considera-a mais fechada:

Eu acho que aqui em casa o pessoal é mais fechado, né? Não sou de conversar com eles [os irmãos], sou de conversar mais com minha mãe... Mas a minha mãe não conversa, e nem eu procuro conversar com ela sobre sexo ou drogas, por exemplo... Eu acho que a família de outros amigos são mais, assim, relacionadas com eles... Eu acho isso legal... em certos pontos a família deles é mais legal do que a minha...

Para ele, a família não é o lugar no qual ele pode explicitar os dilemas da fase que vivencia, como a descoberta da sexualidade ou as drogas. Nem na família nem em outros espaços, como a escola, esses jovens têm canais de comunicação com o mundo adulto. A sua família assume uma postura permissiva em relação ao estilo. A mãe não interferia em sua escolha pela música funk, vendo nela a evidência de um momento que iria passar quando mais velho, mas sem acreditar muito nos seus resultados futuros. Apesar das críticas à sua família, Flavinho considera que ela constitui um núcleo de proteção e segurança, cumprindo um importante papel na sua vida.

Flavinho nunca havia trabalhado até o momento da entrevista. A sua condição de "caçula" lhe permitiu essa "regalia", sendo também uma estratégia familiar para garantir os seus estudos. Ele expressa uma realidade comum a milhares de jovens que se encontram na expectativa do primeiro emprego. Segundo ele, existe o acordo de sua mãe sustentá-lo enquanto permanecer na escola. Ele considera suas condições de vida melhores do que daqueles que trabalhavam, como seu colega de dupla:

Acho que minha situação é melhor que a de Leo, porque posso ver os amigos todos os dias, ficar em casa, almoçar em casa, me divertir, dormir a hora que for... Nessa hora eu estou melhor, mas se for olhar a situação depois eu acho que a minha é pior, ele pode comprar as coisas dele...

Apesar disso, vivia uma certa preocupação diante das possibilidades reais de encontrar algum emprego: "De vez em quando eu paro pra pensar: 'Né, será que um dia eu vou trabalhar?' É uma coisa que vem na cabeça assim, porque é foda, as coisas como estão aí fora...”.

Mas naquele momento, envolvido com a música, com tempo livre e disponível, sem um desejo mais definido em relação a alguma ocupação, além de não sofrer pressões da família, ele tinha todos os motivos para permanecer numa certa inércia, sem enfrentar, de fato, a labuta que é a procura de trabalho. Flavinho, por enquanto, pretende ser um cantor de funk, sonhando sobreviver da atividade artística e, nessa expectativa, não alimenta outro sonho profissional. Vive imerso no presente, não acreditando nas possibilidades de intervir no seu futuro, adiando as preocupações com a sua sobrevivência.

Flavinho cursa o $1^{\circ}$ ano do ensino médio em uma escola estadual. A escola é a única atividade fixa que ele tem no seu cotidiano, além de ser a única instituição pública na qual pode ter acesso aos bens culturais e a um espaço de reflexão metódica sobre si mesmo e sobre o mundo. Mas a escola não consegue envolvêlo, tornando-se uma obrigação necessária que ele apenas suporta. Além disso, a instituição não se mostra sensível à realidade vivenciada pelos alunos fora de seus muros. Flavinho lembra que "[...] a escola tem muito funkeiro, mas eu acho que os professores vão contra o funk... porque assim, eles nem sabem que todos os alunos lá gostam do funk... eu mesmo, nenhum professor sabe que eu escrevo letras, nem a de Português...". 
Para ele, a escola carrega poucos significados sob o aspecto de espaço de socialização. É uma experiência distante dos seus interesses, que pouco contribui para a sua construção como sujeito.

Flavinho está ligado ao funk desde os 15 anos, encontrando nesse estilo o som, as práticas de sociabilidade e os símbolos que se tornaram referência para estruturar uma condição juvenil que se inaugurava. A ligação com a galera do bairro, o sair à noite, o visual que passa a adotar e, principalmente, a freqüência aos bailes, são sinais visíveis que funcionam como mecanismos simbólicos para demarcar a sua identidade como jovem.

O estilo funk ${ }^{8}$ tem como epicentro os bailes, em torno do qual se articula uma identidade própria. Esse é o programa preferido de Flavinho, quase uma obrigação nos finais de semana. É também no baile que ele pode expressar os outros elementos do estilo: o encontro com os amigos, o gosto pela música funk, um determinado jeito de dançar, ressaltando a festa, a fruição do prazer e a alegria de estarem juntos. Mas o baile é também a oportunidade de se mostrar como MC. ${ }^{9}$ Para Flavinho, cantar em bailes é uma emoção muito grande, sendo uma forma de tornar-se conhecido, principalmente no bairro e pelas meninas, além de ampliar seu círculo de relações no meio funk.

Na dupla, é Flavinho quem escreve as letras, caracterizadas por temas que abordam as relações afetivas, a descrição dos próprios bailes e sua animação, sendo comum também a abordagem de temas jocosos de situações ocorridas na cidade, além da exaltação das diferentes "galeras", resgatando o prazer e o humor que são tão negados no cotidiano desses jovens. ${ }^{10}$ Esses temas são coerentes com o senti-

${ }^{8}$ Para maiores informações sobre o funk, ver Vianna (1987), Cechetto (1997), Herschmann (2000), Dayrell (2001), entre outros.

${ }^{9} \mathrm{MC}$ ou mestre de cerimônia é a forma como os cantores de funk se autodenominam.

${ }^{10}$ No período da realização da pesquisa (entre 1998 e 2000) ainda não havia surgido o chamado "funk coreografia", que ganhou sucesso na mídia por intermédio de grupos como o Tigrão. do que atribui a si mesmo como MC: ser mensageiro da alegria, promovendo a "agitação da galera".

No cotidiano de Flavinho, a música ocupa um lugar central; é nela que ele investe a maior parte do seu tempo. Suas manhãs são curtas, pois geralmente acorda tarde. Além de uma ou outra obrigação doméstica, passa as tardes ouvindo os programas de funk de duas rádios comunitárias da região, nas quais é comum suas músicas serem tocadas a pedido de ouvintes. Fora isso, é encontrar com os amigos, uma outra referência central, principalmente os mais chegados:

Eles [os amigos] ocupam o lugar de irmão mesmo. Com eles eu posso conversar, se eu tô com raiva de alguma coisa posso conversar com eles, desabafar mesmo! Isso é legal. Eles ocupam o lugar de irmão, porque eu não tenho essa intimidade com os meus irmãos, aí eu procuro os meus amigos.

O ponto de encontro é quase sempre em uma praça no bairro vizinho, a única da região. É ali que acontecem os encontros, as paqueras, as brincadeiras ou simplesmente o passar o tempo. Os finais de semana são preenchidos com a música. Geralmente os ensaios da dupla são realizados aos domingos, porque Leo trabalha durante a semana. É nesse dia que escutam músicas, discutem letras, trocam idéias sobre as apresentações que pretendem realizar.

O funk é o eixo em torno do qual Flavinho estrutura suas relações, tanto com os amigos mais próximos quanto com os conhecidos. É a "galera": reconhecem-se no funk, compartilham situações lúdicas, encontram-se nos bailes, principalmente no Vilarinho, sentindo-se parte de uma rede simbólica (Arce, 1999). $\mathrm{O}$ fato de ser um MC contribui para ampliar essa rede: "Com o funk hoje eu vivo pra fazer os outros mais felizes, e eu fiz mais amizades também, e isso é legal... você tá no funk e tá rodeado de amigos. É uma diversão, mas uma coisa divertida que a gente tenta levar pro futuro...". Para Flavinho, o funk não é apenas um espaço de vivência de sociabilidades, mas também um espaço de produção de sociabilidades. 
Nos finais de semana também namora, o que faz nas noites de sábado, antes de ir ao baile, e aos domingos; vem mantendo um namoro de mais de um ano, o que tem significado um aprendizado para ele. É interessante perceber o sentido do namoro nas diferentes fases da vida. Para João, numa fase de transição para a vida adulta, o namoro é parte integrante do projeto de futuro; para Flavinho, o namoro é um momento de experimentação e descoberta do outro.

Quando avalia o seu cotidiano, Flavinho o designa como um pouco vazio, monótono, dizendo que gostaria de ter mais coisas para fazer:

Meu dia-a-dia é muito repetitivo. Um dia é igual ao outro. Coisas que mudam é os bailes, as músicas que eu faço, mas quando não tem nada pra fazer o meu dia é igual ao outro... fica assim meio vazio, porque é repetitivo, você tem de fazer as mesmas coisas porque não tem nada pra fazer...

Naquele momento colocava para si duas alternativas: a realização por intermédio da música, ou viver como um trabalhador pobre, em qualquer atividade que lhe garanta um salário com o qual possa sustentar sua família. Diante das incertezas próprias do nosso tempo e das reduzidas possibilidades de uma inserção social mais qualificada, sua opção é viver o presente, com o que este puder oferecer de prazer. No seu caso, o sonho relacionado à música é o que dá sentido ao seu cotidiano, mas também a esperança que sempre lhe aponta um rumo, de forma a não se perder nas malhas do presente.

\section{Os modos de ser jovem}

As trajetórias de vida de João e Flavinho, bem como o nosso contato com os outros jovens pesquisados, nos levam a constatar que os estilos rap e funk constituem um espaço e um tempo nos quais esses jovens podem afirmar a experiência da condição juvenil. É por meio desses estilos que constroem determinados modos de ser jovem. E nessa construção colocam em questão as imagens, ou um certo "modelo" de juventude.
Uma primeira imagem que questionam é a juventude vista na sua dimensão de transitoriedade. Esses jovens mostram que viver a juventude não é preparar-se para o futuro, para um possível "vir-a-ser", entre outras razões porque os horizontes do futuro estão fechados para eles. O tempo da juventude, para eles, localiza-se no aqui e agora, imersos que estão no presente. E um presente vivido no que ele pode oferecer de diversão, de prazer, de encontros e de trocas afetivas, mas também de angústias e incertezas diante da luta da sobrevivência, que se resolve a cada dia. Não significa que sejam alienados ou passivos, que não nutram sonhos e desejos. Eles os têm, mas com uma especificidade: quase sempre estão ligados a uma realização na esfera musical e à possibilidade de uma vida com mais conforto, principalmente para as mães. No entanto, esses sonhos e desejos não se concretizam necessariamente em projetos de vida, e quando o fazem, se mostram fluidos ou de curto alcance. Assim, eles se centram no presente e nele vão se construindo como jovens, não acreditando nas promessas de um futuro redentor.

Outra imagem que esses jovens colocam em questão é a juventude vista como um momento de crise e distanciamento da família. No nível de aproximação que conseguimos estabelecer com os rappers e funkeiros, foi possível constatar a existência de conflitos familiares, mas em nenhum momento esse quadro conflitivo colocou em questão a família como o espaço central de relações. Ao contrário: no caso desses jovens, o núcleo familiar significou um espaço de experiências estruturantes. As relações que estabelecem, a qualidade das trocas, os conflitos, os arranjos existentes para garantir a sobrevivência e os valores predominantes são dimensões que marcam a vida de cada um, constituindo um filtro por meio do qual traduzem o mundo social e onde inicialmente descobrem o lugar que nele ocupam (Sarti, 1996, 1999).

Essas experiências familiares vêm colocar em questão uma imagem muito difundida sobre as famílias das camadas populares, vistas no ângulo da estruturação $x$ desestruturação, na qual o critério de definição é o modelo de família nuclear, constituída por pai, 
mãe e irmãos. Os dados coletados no mínimo problematizam essa imagem. Grande parte das famílias desses jovens não contam com a presença do pai, organizando-se em termos matrifocais, e nem por isso se mostram "desestruturadas", garantindo, com esforço, a reprodução física e moral do núcleo doméstico. Mais do que a presença ou não do pai, o que parece definir o grau de estruturação familiar é a qualidade das relações que se estabelecem no núcleo doméstico e as redes sociais com as quais podem contar. E nisso a mãe desempenha um papel fundamental. É ela a referência de carinho, de autoridade e dos valores, para a qual é dirigida a obrigação moral da retribuição. Não é de se estranhar que ambos contemplem a mãe nos seus projetos, desejando dar-lhe uma vida mais confortável.

Outra imagem que os jovens colocam em questão é a da juventude como um momento de crise. Naquilo que nos foi possível apreender, não evidenciamos a existência de uma crise na entrada da juventude, muito menos sinais de conflitos atribuídos tipicamente aos adolescentes. Se existe uma crise, esta foi constatada na passagem para a vida adulta. A imagem de adulto que eles constroem é muito negativa. Ser adulto é ser obrigado a trabalhar para sustentar a família, ganhar pouco, na lógica do trabalho subalterno. Mas é também assumir uma postura "séria", diminuindo os espaços e tempos de encontro, com uma moral baseada em valores mais rígidos, abrindo mão da festa, da alegria e das emoções que vivenciam no estilo. Para muitos, ser adulto implica ter de abrir mão do estilo, fazendo dessa passagem um momento de dúvidas e angústias, vivida sempre como tensão. Não que recusem ou neguem essa passagem, mas a vivenciam como uma crise. Uma crise vivida não na entrada da juventude, mas na sua saída.

Finalmente, a trajetória desses jovens questiona a visão romântica da juventude. A realidade dos rappers e funkeiros pesquisados evidencia que a juventude para eles não corresponde a essa imagem. Ao contrário, é um momento duro, de dificuldades concretas de sobrevivência, de tensões com as instituições, como no caso do trabalho e da escola.

A realidade do trabalho aparece na sua precarie- dade, expressão da crise da sociedade assalariada, que atinge principalmente os jovens pobres. A relação desses jovens com o mercado expressa uma lógica presente na sociedade brasileira contemporânea, que, segundo Martins, cria uma massa de população à margem, com pouca chance de ser, de fato, reincluída nos padrões atuais do desenvolvimento econômico. Segundo ele, "o período da passagem do momento da exclusão para o momento da inclusão está se transformando num modo de vida, está se tornando mais do que um momento transitório" (1997, p. 33).

Vivendo de "bicos", a maioria deles vem investindo na possibilidade de sobreviver da atividade artística, ou pelo menos de um trabalho autônomo ligado de alguma forma à área cultural. O trabalho aparece como obrigação necessária, vivido como empecilho às atividades musicais, por isso sonham com um trabalho expressivo, no qual possam realizar-se pessoalmente. Essa postura pode ser vista como expressão de uma recusa, mesmo que provisória, das condições que a sociedade lhes oferece para a sua inserção social. Mesmo aqueles que vivem ainda as incertezas da expectativa do primeiro emprego, como Flavinho, mostram-se descrentes do que o mundo do trabalho possa lhes oferecer.

Podemos afirmar que o mundo do trabalho pouco contribuiu no processo de humanização desses jovens, não lhes abrindo perspectivas para que pudessem ampliar suas potencialidades, muito menos construir uma imagem positiva de si mesmos. É um dos espaços do mundo adulto que se mostra impermeável às necessidades dos jovens em construir-se como sujeitos.

Já as experiências escolares desses jovens evidenciam que a instituição se coloca distante dos seus interesses e necessidades, não conseguindo entender nem responder às demandas que lhe são colocadas, pouco contribuindo também em sua construção como sujeitos. Enfim, esses jovens expressam um contexto de uma nova desigualdade social, numa sociedade que apenas lhes abre perspectivas frágeis e insuficientes de inclusão (Martins, 1997).

Nesse contexto, os estilos rap ou funk, mesmo com abrangências diferenciadas, significaram uma 
forte referência na elaboração e na vivência da condição juvenil dos jovens pesquisados. Para todos, representaram uma ampliação dos circuitos e redes de trocas, sendo o meio privilegiado pelo qual se introduziram na esfera pública. Na gratuidade daquelas relações e nas atividades de lazer, vieram construindo formas de sociabilidade próprias, num exercício de convivência social, aprendendo a conviver com as diferenças. A vivência do estilo possibilitou a esses jovens práticas, relações e símbolos por meio dos quais se afirmaram com uma identidade própria, como jovens. Enfim, o estilo se coloca como mediador de um determinado modo de ser jovem.

Podemos dizer que, através do rap ou do funk, os jovens vivenciam a tentativa de alongar o período da juventude o máximo que podem, experienciando assim uma moratória. O sentido dessa tentativa não é tanto o de uma suspensão da vida social ou de irresponsabilidade, como geralmente é vista, mas de garantir espaços de fruição da vida, de não serem tão exigidos, de se permitirem uma relação mais frouxa com o trabalho, de investirem o tempo na sociabilidade e nas trocas afetivas que esta possibilita. É o envolvimento com o rap ou com o funk que cria, possibilita e legitima a moratória como uma experiência válida.

Ao mesmo tempo, o estilo de vida rap e funk possibilita a muitos desses jovens uma ampliação significativa das hipóteses de vida (Giddens, 1995), abrindo espaços para sonharem com outras alternativas de vida que não aquelas restritas, oferecidas pela sociedade. Mas as perspectivas são muito reduzidas. Na prática, o estilo possui limites, não articulando uma resposta para as questões centrais, como profissionalização e sobrevivência, principalmente durante a passagem para a vida adulta. Vários deles, como João, mesmo com o passar da idade e assumindo compromissos familiares como o noivado, continuam a insistir. Mas a grande maioria desiste, vê-se obrigada a abandonar o sonho com a carreira musical, uma vez que não mais consegue conciliála com as necessidades de sobrevivência. Assim, o estilo torna-se uma opção provisória, mesmo que seja mais longa para alguns desses jovens. Para a maioria deles, a vivência da juventude é muito intensa, mas curta.
Podemos constatar que os rappers e os funkeiros parecem reelaborar as imagens correntes sobre a juventude, criando modos próprios de ser jovem, sempre mediados pelo estilo. No contexto de transformações socioculturais mais amplas pelo qual passa $o$ Brasil, parecem surgir novos lugares no mundo juvenil, quase sempre articulados em torno da cultura. O mundo da cultura se apresenta mais democrático, possibilitando espaços, tempos e experiências que permitem que esses jovens se construam como sujeitos. Mas não podemos esquecer que, no Brasil, a modernização cultural que influencia tanto a vida desses jovens não é acompanhada de uma modernização social. Assim, se a cultura se apresenta como um espaço mais aberto é porque os outros espaços sociais estão fechados para eles. Portanto, não podemos cair numa postura ingênua de supervalorização do mundo da cultura como apanágio para todos os problemas e desafios enfrentados pelos jovens pobres. No contexto em que vivem, qualquer instituição, por si só - seja a escola, o trabalho ou aquelas ligadas à cultura -, pouco pode fazer se não estiver acompanhada de uma rede de sustentação mais ampla, com políticas públicas que garantam espaços e tempos para que os jovens possam se colocar de fato como sujeitos e cidadãos, com direito a viver plenamente a juventude.

JUAREZ DAYRELL, doutor pela Faculdade de Educação da USP, é professor adjunto da Faculdade de Educação da UFMG. Organizou a coletânea Múltiplos olhares sobre educação e cultu$r a$, editado pela Editora da UFMG, e publicou diversos artigos sobre o tema da juventude, entre eles: O rap e o funk na socialização da juventude (Educação e Pesquisa, v. 28, p. 117-136, jan.jun.) e Cultura e identidades juveniles (Revista Ultima Decada, CIDPA, Chile, $\mathrm{n}^{\circ} 18$, p. 69-91, abr. 2003). Linha de pesquisa atual: Educação e Juventude. E-mail: juarez@ fall.ufmg.br.

\section{Referências bibliográficas}

ABRAMO, Helena, (1994). Cenas juvenis: punks e darks no espetáculo urbano. São Paulo: Escrita. 
ABROMAVAY, Miriam et al., (1999). Gangues, galeras, chegados e rappers: juventude, violência e cidadania nas cidades da periferia de Brasília. Rio de Janeiro: Garamond.

ANDRADE, Elaine Nunes, (1996). Movimento negro juvenil: um estudo de caso sobre jovens rappers de São Bernardo do Campo. Dissertação de mestrado. Faculdade de Educação da USP.

ARCE, José Manuel Valenzuela, (1999). Vida de barro duro: cultura popular juvenil e grafite. Rio de Janeiro: Editora UFRJ.

CECHETTO, Fátima Regina, (1997). Galeras funk cariocas: o baile e a rixa. Dissertação de mestrado. Departamento de Ciências Sociais da UERJ.

CHARLOT, Bernard, (2000). Da relação com o saber: elementos para uma teoria. Porto Alegre: Artemed.

COSTA, Maria Regina, (1993). Os carecas de subúrbio: caminhos de um nomadismo moderno. Petrópolis: Vozes.

DAYRELL, Juarez, (1999). Juventude, grupos de estilo e identidade. Educação em Revista, n ${ }^{\circ}$ 30, p. 25-39, dez. (2002b). Juventude, produção cultural e a escola. Caderno do Professor. Secretaria Estadual de Educação de MG, Belo Horizonte, ${ }^{\circ}$ 9, abr.

(1996). Múltiplos olhares sobre educação e cultura. Belo Horizonte: Editora UFMG.

(2001). A música entra em cena : o rap e o funk na socialização da juventude em Belo Horizonte. Tese de doutorado. São Paulo: Faculdade de Educação.

, (2002a). O rap e o funk na socialização da juventude. Educação e Pesquisa, v. 28, n 1, p. 117-136, jan.-jun.

FEIXA, Carlos, (1998). De jóvenes, bandas e tribus. Barcelona: Ariel.

GIDDENS, Anthony, (1995). Modernidad e identidad del yo: el yo y la sociedad en la época contemporânea. Barcelona: Península.

GUERREIRO, Goli. (1994). Retratos de uma tribo urbana : rock brasileiro. Salvador: Centor Editorial e Didático da UFBA.

GUIMARÃES, Maria Eloísa, (1995). Escola, galeras e narcotráfico. Tese de doutorado. Departamento de Educação da PUC/RJ.

HERSCHMANN, Micael, (2000). O funk e o hip hop invadem a cena. Rio de Janeiro: Editora UFRJ.

KEMP, Kenia, (1993). Grupos de estilo jovens: o rock underground e as práticas (contra) culturais dos grupos "punk" e "trash" em São Paulo. Dissertação de mestrado. Departamento de Antropologia da UNICAMP.
LECCARDI, Carmem, (1991). Orizzonte del tempo: esperienza del tempo e mutamento sociale. Milano: Franco Angeli.

MARTINS, José de Souza, (1997). Exclusão social e a nova desigualdade. São Paulo: Paulus.

MELUCCI, A., FABBRINI, Anna, (1992). L'età dell'oro: adolescenti tra sogno ed esperienza. Milano: Feltrinelli.

MORCELLINI, Mario, (1997). Passagio al futuro: formazione e sociallizzazione tra vecchi e nuovi media. Milão: Franco Angeli.

PAIS, José Machado, (1993). Culturas juvenis. Lisboa: Imprensa Nacional/Casa da Moeda.

PERALVA, Angelina, (1997). O jovem como modelo cultural. Revista Brasileira de Educação, São Paulo, ANPEd, n 5/6.

SALEM, Tânia, (1986). Filhos do milagre. Ciência Hoje, SBPC, v. $5, n^{\circ} 25$, p. $30-36$, jul.-ago.

SARTI, Cynthia, (1996). A família como espelho: um estudo sobre a moral dos pobres. Campinas: Autores Associados.

, (1999). Família e jovens no horizonte das ações. Revista Brasileira de Educação, São Paulo, nº 11, maio-ago.

SILVA, José Carlos Gomes, (1998). Rap na cidade de São Paulo: música, etnicidade e experiência urbana. Tese de doutorado. Departamento de Ciências Sociais do Instituto de Filosofia e Ciências Humanas da UNICAMP.

SPOSITO, Marília, (1993). A sociabilidade juvenil e a rua: novos conflitos e ação coletiva na cidade. Tempo Social, Revista de Sociologia da USP, São Paulo, v. 5, nº 1 e 2, p. 161-178. , (2000). Estado do conhecimento: juventude. Brasília: INEP.

TELLA, Marco Aurélio Paz, (2000). Atitude, arte, cultura e autoconhecimento; o rap como voz da periferia. Dissertação de mestrado. Departamento de Ciências Sociais da PUC/SP.

VIANNA, Hermano, (1987). O mundo funk carioca. Rio de Janeiro. Jorge Zahar Editor.

, (org.), (1997). Galeras cariocas: territórios de conflitos e encontros culturais. Rio de Janeiro: Editora da UFRJ.

ZALUAR, Alba, (1997). Gangues, galeras e quadrilhas: globalização, juventude e violência. In : VIANNA, Hermano (org.). Galeras cariocas, territórios de conflitos e encontros culturais. Rio de Janeiro: Editora da UFRJ. p. 17-58

Recebido em dezembro de 2002 Aprovado em abril de 2003 